@ @TheBJReview

\title{
Why Ofcom must find its backbone
}

\section{Steven Barnett and Fulian Petley}

Two new television channels plan to offer British audiences a more partisan interpretation of the news. Who mill ensure they play within the rules?

In 2007, below a headline that read "Why Rightwingers Are On The Warpath", the former Independent on Sunday and New Statesman editor Peter Wilby wrote in The Guardian: "The British right hopes to emulate the success of the US right in convincing the public that the main organs of news and opinion are gripped by a left-wing conspiracy... [their aim] is to alter the definition of the 'middle ground' in British life, moving it to the right of any government of the past 30 years."

It was not a new idea. Just three years earlier, the director of an obscure right-wing think tank called the New Frontiers Foundation had stated in a long blogpost: "There are three structural things that the right needs to happen in terms of communications... 1) the undermining of the BBC's credibility; 2) the creation of a Fox News equivalent/talk radio shows/ bloggers etc to shift the centre of gravity; 3) the end of the ban on TV political advertising." Its author was Dominic Cummings, and in the year that he effectively ran Downing Street for Boris Johnson, he showed considerable determination to bring about the first two conditions.

Putting aside the current government's demonstrable hostility towards the $\mathrm{BBC}$, how would the right go about fulfilling Cummings' second challenge? Standing in the way of overtly politically partisan news channels on the broadcast media are the UK's longstanding and well-supported impartiality rules, responsible for ensuring that not just the BBC, but its commercial TV and radio rivals are among the most trusted news and information sources in the country. 
For evidence, we need look no further than the six months of the Covid-19 pandemic during which Ofcom systematically measured trust in information sources. Around two-thirds of those who used broadcast sources said they trusted broadcasters for news and information about the virus - rising to three-quarters for BBC radio and online, and for Channel 4. This compared to less than half for both the mid-market and red-top press, just over a third for Twitter and YouTube, and a miserable - if perhaps reassuring - 16 per cent for Facebook.

Other data confirm the longstanding evidence that news organisations subject to impartiality rules command far greater trust from news consumers than those free to editorialise. An Ipsos-MORI survey from April-May 2019 which asked respondents which one news source they turn to for impartial news found that 44 per cent said the BBC, followed by 10 per cent for ITV, 6 per cent for Sky and 5 per cent for Channel 4 . The same survey found very similar figures when respondents were asked which one news source they would turn to for news they can trust.

Despite overwhelming evidence for the continuing civic and democratic value of UK broadcasting's impartiality regime, self-interested competitors in the news business have a long history of attempting to influence policymakers and regulators to abandon the concept in favour of allowing overt partisanship. In 2009, anticipating a general election in which the Murdochs were seeking to influence the policy agenda of - they hoped - an incoming Conservative government, James Murdoch called impartiality "an impingement on freedom of speech and on the right of people to choose what kind of news to watch". In an irony that will have been lost on Murdoch himself, his speech was titled "The Absence of Trust".

Murdoch and his father would have been well aware of what had happened a little over 20 years earlier in the United States. Until 1987, America followed its own version of an impartiality regime, known as the "fairness doctrine" - a combination of case law, regulatory action and congressional legislation that required broadcasters not only to cover issues of great public importance but also to ensure that such coverage was balanced. It became a victim of neo-liberal market policies in the 1980s when the Reagan-appointed Federal Communications Commission (FCC) decided that this doctrine was inconsistent with the freedom of expression guaranteed by the First Amendment.

So, in 1987, the FCC voted to abolish it altogether. At the heart of this regulatory decision, upheld in the Court of Appeals in 1989, were two 
interlinked principles which still underpin American media policy: a visceral hostility to any suggestion that the state should influence content, and a fundamental belief in the free market as the only guarantor of quality and choice for consumers - a devotion to "free market" theory that completely ignores the power of corporate speech and the ability of wealthy individuals to dictate it.

On the back of this Reagan-inspired deregulation - which advanced corporate interests at the expense of the public interest - Murdoch launched his Fox News Channel in 1996 with an overtly right-wing news agenda quite at odds with the basic tenets of Fourth Estate journalism. For more than 20 years, Fox insisted that its coverage was "fair and balanced", offering the specious justification that it was providing "balance" to the "left-wing" journalism of NBC, ABC and CBS. Despite dropping the tagline in 2017, Fox executives and their defenders have continued to peddle the same argument. In fact, the mainstream networks appear "left-wing" only when viewed from a vertiginously conservative perspective.

\section{Subbead}

Watching the newcomer's ratings success, other broadcasters began to shift their own centre of gravity and to increase the volume of opinionated material in their news programmes, with the result that television journalism began to lose much of the trust it had earned in the first five decades of its existence. It is not too far-fetched to suggest that, without the full-throated support of Fox News commentators such as Tucker Carlson and Laura Ingraham - including uncritical recycling of Trump propaganda and conspiracy theories - Donald Trump might never have been elected in 2016, nor enjoyed the same level of support in the 2020 election.

And now, just as Trump (if not Trumpism) is consigned to presidential history, two partisan news channels are being planned for the UK. One is, inevitably, being driven by Murdoch, seeking to exploit the resources of the four national newspapers and three national commercial radio stations he already owns, although details of his new venture are thin on the ground. The other is GB News, which acquired a broadcast licence from Ofcom last year and emanates from the company All Perspectives. This is jointly owned by Andrew Cole and Mark Schneider, respectively current and former directors of Liberty Global, which owns Virgin Media. The company's largest shareholder is the US billionaire John Malone. The largest individual 
landowner in the States (with 2.2million acres) and widely known as the "cable cowboy", he is a member of the board of directors of the hard rightwing Cato Institute and donated \$250,000 to Donald Trump's inauguration in 2017. The chair of GB News is Andrew Neil, chief executive of the Spectator and chair of the Barclay Brothers' Press Holdings, who will also be presenting a prime-time programme on the new channel.

In January, GB News announced funding from the Dubai-based Legatum Institute, described by the Financial Times in 2017 as "one of Britain's loudest intellectual advocates for a 'hard' Brexit”. Founded by Tory peer Philippa Stroud (a former special adviser to Iain Duncan Smith when he was work and pensions secretary), it enjoys very close relationships with prominent right-wing Tories such as Michael Gove and Steve Baker. It is notoriously loath to disclose the sources of its funding, but, according to DeSmog UK, it received a grant of $\$ 77,000$ from the Charles Koch Charitable Foundation, which, like other Koch family foundations, is heavily involved in climate change denial.

The other major funder announced in January was Sir Paul Marshall, cofounder and director of asset management firm Marshall Wace, one of the biggest hedge funds in Europe. According to Tim Shipman's All Out War, Marshall played the key role in persuading the then-justice minister, Michael Gove, to betray David Cameron and lead the official campaign to leave the EU, to which he donated $£ 100,000$. He has also funded the political website Unherd, which hosts an array of right-wing writers with a mission statement "to push back against the herd mentality with new and bold thinking".

Cole informed his LinkedIn followers that the BBC was "possibly the most biased propaganda machine in the world" and asked them to watch out for 'the launch of a completely new TV news channel for the UK - one that will be distinctly different from the out-of-touch incumbents". GB News has also hired former Sky News executive John McAndrew and appointed Angelos Frangopoulos, the former head of Sky News Australia, as chief executive. Serving there for 20 years, he replicated the Fox News formula of rolling news reporting during the day, followed by unashamed right-wing punditry in the evening. This became far more pronounced after Murdoch took full ownership of the channel in December 2016, and was recently described by Prospect magazine as featuring “a Who's Who of Murdoch's star print columnists who make no secret of their hard-right credentials, making frequent targets of anyone deemed vaguely hostile to their ideological worldview". 
This pattern of ramping up inflammatory right-wing rhetoric in order to increase ratings has been a pattern for Murdoch's news channels in both Australia and the US, in both cases turning over their evening slots to partisan, opinionated hosts pushing hard-right narratives on issues such as climate change, immigration and identity politics. In an excoriating profile of the Murdoch news empire, The New York Times related how, in 2018, neoNazi leader Blair Cottrell - who had recently been fined for "inciting contempt for Muslims" - appeared on a Sky News show in Australia, calling on his countrymen to "reclaim our traditional identity as Australians" and advocating restrictions on immigration to those "who are not too culturally dissimilar from us".

Sky News subsequently apologised, but the row had done its job: created publicity for the channel and signalled to the country's racists, white supremacists and conspiracy theorists that they were not alone. Meanwhile, several Fox News hosts continued to indulge the fantasy that the 2020 election had been stolen from Trump. Undeterred by the insurrectionists who invaded the Capitol (prime-time Fox News host Laura Ingraham spent most of one programme arguing that Trump protesters had been infiltrated by antifa), Fox has subsequently doubled down on its propaganda-led approach by replacing its $7 \mathrm{pm}$ news show with another partisan programme.

\section{Subbead}

There is thus little doubt about the direction Britain's two new channels intend to take. And we have seen the potential consequences for a healthy democracy when news channels are exploited as part of a propaganda war. As James Murdoch himself said in an interview with the Financial Times following the Capitol mob invasion - without naming names - "those outlets that propagate lies to their audience have unleashed insidious and uncontrollable forces that will be with us for years. I hope that those people who didn't think it was that dangerous now understand, and that they stop". The question which both putative launches raise for the UK is whether its longstanding impartiality regime - which lies at the heart of British audiences' abiding trust in broadcast news - is strong enough to withstand what will certainly be a formidable challenge. More importantly, will the regulator Ofcom be sufficiently robust to uphold that regime despite an inevitable assault from the Murdoch press and other right-wing papers? 
On paper, there should not be an issue. The UK's impartiality regime for commercial broadcasters dates back to the beginning of ITV in 1955, and was then administered by the Independent Television Authority (ITA). Its most recent incarnation stems from the Communications Act 2003, which lays on Ofcom the obligation to ensure for every licensed broadcaster that "news, in whatever form, is reported with due accuracy and presented with due impartiality [and that] due impartiality is preserved when dealing with matters of political and industrial controversy and matters of current public policy".

Ofcom gives effect to this obligation through its Broadcasting Code. Crucially, that code elaborates on its interpretation of $d u$ impartiality with the qualification that it "may vary according to the nature of the subject, the type of programme and channel, the likely expectation of the audience as to content, and the extent to which the content and approach is signalled to the audience".

On the one hand, such discretion allows Ofcom to license channels that originate from outside the UK - such as Al Jazeera, RT, and even Fox News until 2017 - on the reasonable assumption that viewers appreciate the different cultural origins of such channels. Worryingly, however, it appears that such flexibility has recently been extended to Murdoch's radio stations in the UK, in particular to his talkRADIO station on which Sun executive editor Dan Wootton frequently uses his Drivetime programme to give uncontested airtime to anti-BBC campaigners and propagandists (at the end of January, Wootton was announced as the first big on-screen hiring for GB News, with his own daily show). In the current political climate - as the avowedly right-wing government of Boris Johnson seeks to cement its postBrexit political message and his acolytes pursue a Trump-style culture war - such partisan broadcast channels could easily become a vital weapon in the political armoury, exactly as "shock jocks" did in the US after the fairness doctrine was abolished.

A major problem here is that when Ofcom comes to make judgments on the "due impartiality" of the two new channels' programming, it will have to do so in a highly politically charged environment ravaged by the culture wars. Here the idea that the BBC is "left-wing" or a propaganda organ of the "liberal metropolitan elite" is loudly proclaimed daily by newspapers with political and economic axes to grind, by libertarian think tanks for whom the BBC prevents a "free market" in broadcasting from emerging, by self-proclaimed media "experts" such as News-watch, and by that section 
of the Tory party which has always regarded the $\mathrm{BBC}$ as a nest of pinkos.

In this respect, it is significant that Andrew Cole considers The Guardian "a disgusting, extremist rag" and Bloomberg "very suspect" and "almost unreadable". The only conclusion that one can draw from this dismal chorus of invective, almost entirely devoid of empirical evidence for its alarmist claims, is that only journalism which stems from its own right-wing perspective is "fair and balanced".

Of course, one of the reasons why right-wing newspapers and their readers complain endlessly about "liberal bias" in the BBC is that BBC journalism is indeed different from the kinds of journalism that today define the Sun, Mail, Express, Telegraph and Times, which, between them, constitute the dominant ideological strand of the UK's daily press. But the crucial point here is whether broadcasters should seek, or indeed be permitted, to emulate the hyper-partisan form of journalism that characterises much of the UK daily press or whether their journalistic output should adhere to the well-entrenched values of impartiality and accuracy. These are, in fact, the values which are intrinsic to the Fourth Estate ideal of journalism, and such journalism is one of the hallmarks of a democratic society.

\section{Subbead}

Such values stem ultimately from the Enlightenment project, and if the core purpose of that project is rational enquiry in order to explain the society in which we live, then the journalism which springs from that project is bound to privilege qualities such as reason, proof, accountability, accuracy, truthfulness, disinterestedness, assessability and scepticism - particularly towards political propaganda, received opinions and "commonsense" explanations of social reality. But these are also essentially liberal values, albeit with a small "l", thus making it perfectly possible for an avowedly left- or right-wing journalist to endorse the values - perhaps methodology is a better word - of the Fourth Estate. Consequently, the BBC should not be so defensive when accused of being liberal. Indeed, it should regard such a charge as a journalistic badge of honour.

The launches of these new channels, then, will pose fundamental challenges for Ofcom and the impartiality regime which it oversees. In particular, will it be so naïve as to fall for the threadbare ideological conjuring trick that the new entrants are simply providing the "balance" to the allegedly over-liberal BBC? And, underlying this question, will it have the 
institutional strength to take on the extremely powerful political and economic interests invested in these initiatives?

If not, a scenario could easily develop in which the BBC, which already stands accused of shadowing the agenda of the right-wing press, does likewise with that of the new channels. On the other hand, if it doesn't follow suit, it could soon find its news coverage being compared unfavourably with the new channels, attracting yet more criticism for being overly "liberal" - not only by right-wing newspapers and politicians but now by right-wing television channels as well. It would then be under huge pressure to shadow their news agenda as a defensive move. In either case, broadcast news in the UK falls prey to exactly the same process of Foxification that Murdoch so successfully initiated in the States and Australia.

Clearly, then, a great deal hinges on the way in which Ofcom handles GB News and Murdoch's new channel, which will have huge ramifications not just for the UK broadcasting ecology but for the quality of news, trusted journalism, informed debate and ultimately for democracy itself. With a new chair yet to be appointed - and bound to be a highly politicised appointment - Ofcom will be facing one of the biggest challenges of its existence. Let's hope it is up to the task.

Steven Barnett is professor of communications at the University of Westminster and a member of the BJR board. Fulian Petley is emeritus and honorary professor of journalism at Brunel University London and a member of the BJR board. 